\title{
PERBEDAAN KEPADATAN LALAT YANG HINGGAP PADA FLY GRILL YANG BERBEDA WARNA DI PAJAK SINGA KOTA KABANJAHE KABUPATEN KARO TAHUN 2018
}

\author{
Erba Kalto Manik, Susanti br Perangin-Angin \\ Jurusan Kesehatan Lingkungan Poltekkes Kemenkes RI Medan
}

\begin{abstract}
Flies are Arthropoda insects that belong to the order of Diptera. Flies can transmit the disease through all the limbs such as feces, vomit, body hair, limb hair and especially on the legs that have fine hairs so that the seeds of the disease can stick. Flies have a life activity interacting with a place that is a habitat for diseases such as trash, feces and carcasses. Plus its ability to fly 1-2 miles of several species of flies can spread several diseases such as Thgypoid Fever, Parathypoid, bacillary dysentery, amoebic dysentery, and several eye diseases from various places that have been visited. Flies are insects in general having sensitivity to different light wavelengths (colors). This research is a field experiment and includes a Pre Experiment that is Postest Only Design which aims to analyze differences in the density of flies that land on Fly Grill which are different colors in Singa Kabanjahe Tax to plan control efforts which are about when, where and how control will be carried out. in the Singa Kabanjahe Tax TPS for 10 days and the number of flies perched with different fly grill colors (orange, pink, light blue, light green and yellow) for 30 seconds, calculating 10 times the calculation with the highest average. The data obtained were analyzed by ANOVA test with an error rate of 0.05. From the ANOVA test data with $=0.05$ shows $p=0.221$, which means that there is no difference in density of flies perched on a different color fly grill. The average density of flies, from the lowest to the highest is as follows: fly grill in orange, light green, light blue, pink and yellow ... The conclusion that can be drawn is that flies do not like orange, light green and light blue. Meanwhile, the color favored by flies is yellow
\end{abstract}

Keywords : fly grill color, fly density

\section{PENDAHULUAN}

Lalat adalah serangga jenis Arthropoda yang masuk dalam ordo Diptera. Beberapa spesies lalat mempunyai peranan penting dalam masalah kesehatan masyarakat. Serangga ini dapat menjadi vector mekanik dan biologis dalam penyebaran penyakit. Hal ini karena aktivitas lalat dalam mencari makan dan berkembangbiak. Lalat dapat menularkan penyakit melalui semua anggota tubuhnya seperti feces, muntahan, bulu badan, bulu anggota gerak( Sayono, 2005). Dan terutama pada kaki yang terdapat bulu-bulu halus sehingga bibit-bibit penyakit dapat menempel (Suraini,2013). Reproduksi lalat sangat cepat, secara umum siklus hidup lalat membutuhkan waktu 15 hari, dan dapat meningkat atau menurun tergantung dari factor lingkungan ( Sayono, et al.2005)..

Lalat rumah mampu menghasilkan telur $100-150$ butir dalam tiap kali peneluran dan sepanjang hidupnya lalat betina mampu menghasilkan telur sebanyak lebih kurang 2000 butir. Tingkat perkembangbiakan lalat bervariasi, dan dapat meningkat apabila berada pada lingkungan yang sesuai dan banyak mengandung bahan organik yang membusuk (Hastutick \& Fitri, 2007).

Lalat mempunyai aktivitas hidup berinteraksi dengan tempat yang menjadi habitat penyakit seperti tempat sampah, tinja dan bangkai. Ditambah lagi kemampuannya yang mampu terbang 1-2 mil beberapa species lalat mampu menyebarkan beberapa penyakit seperti Demam Thgypoid, Parathypoid, Disentri basiler, Disentri amuba, dan beberapa penyakit mata dari berbagai tempat yang pernah disinggahi. Selain berinteraksi dengan tempat habitat agen penyakit, lalat juga berinteraksi dengan manusia kerana makanan lalat adalah zat gula yang ada pada makanan manusia (Darmawati et al,2005). Lalat juga dapat menyebarkan organisme pathogen seperti kista protozoa, bakteri, enterovirus ( El-Sherbini \& El-Sherbini, 2011) dan telur cacing seperti Ascaris lumbricoides, Trichuris trichiura, Enterobius vermicularis, Taxocara canis dan Strongiloides stercoralis dan tropozoid (Onyenwe et, al,2016).

Keberadaan lalat terkait dengan adanya bahan organik seperti sampah dan makanan, dan tingkat reproduksi lalat dapat meningkat apabila berada pada kondisi lingkungan yang sesuai terutama pada tempat yang banyak mengandung buahan organic membusuk. Karena hal tersebut tempat seperti pasar, tempat sampah dan tempat pengolahan makanan merupakan tempat potensial untuk perkembangan lalat (Sayono, et al.2005)

Lalat menyenangi tempat perindukan yang kondisinya basah, sampah basah, tinja dan bahan busuk, selain itu 
dengan kebiasaan lalat menyukai dan tertarik dengan makanan yang dimakan oleh manusia seperti makanan yang masih segar seperti sayuran, buah serta daging yang sering dikonsumsi manusia setiap harinya ditempat itulah lalat beristirahat dan tempat perkembangbiakannya. Selain itu, tempat yang disenangi adalah sampah yang sebagai tempat untuk bersarang dan berkembangbiak (Dwiyatmo, 2007).

Data dari Profil Kesehatan Propinsi Sumatera Utara tahun 2008, diare menduduki urutan kedua dari sepuluh penyebab terbanyak kunjungan ke Puskesmas setelah influenza dengan kematian pada penyakit diare mengalami peningkatan dibandingkan tahun sebelumnya. Tahun 2008 Case Fatality Rate (CFR) akibat diare sebesar 4,78\% dengan 10 penderita meninggal dari 209 kasus. Angka ini naik dari sebelumnya yaitu dengan CFR 1,31\% dengan 4 penderita meninggal dari 304 kasus.

Berdasarkan Profil Kesehatan Kabupaten Karo pada tahun 2010 jenis penyakit menular yang dilaporkan di Kabupaten Karo penyakit diare masih tinggi dan berada pada posisi ke-4 dari 10 penyakit terbanyak yaitu sebanyak 12.494 kasus , $3.518(27,17 \%)$ kasus terjadi pada anak balita.

Pasar adalah salah satu tempat umum dimana berkumpulnya orang-orang untuk melakukan kegiatan transaksi jual-beli barang-barang untuk kehidupan seharihari. Sebagai tempat umum,sangatlah perlu adanya pengawasan terhadap sanitasi pasar.pengawasan dilakukan untuk mencegah terjadinya penularan penyakit, baik antara pedagang dengan pembeli, pedagang dengan pedagang, ataupun antara pembeli dengan pembeli.Salah satu pengawasan sanitasi pasar adalah dengan melakukan pengukuran kepadatan lalat dan identifikasi jenisnya serta melakukan upaya pengendalian lalat.

Berdasarkan pengamatan peneliti bahwa Pajak Singa Kota Kabanjahe masih dikategorikan pasar tidak sehat yang mencakup dari lokasi, bangunan pasar, sanitasi, PHBS, keamanan dan fasilitas lain. Sebagai pasar holtikultura tidak terlepas dari keberadaan lalat. Berdasarkan survey awal, ditemukan banyak lalat pada tempat-tempat tertentu seperti tempat penjualan daging, tempat penjualan sayuran, tempat penjualan ikan dan tempat penjualan buah yang menunjukkan adanya lalat yang hinggap. Kemudian kondisi sanitasi lingkungan pasar, seperti tempat pembuangan sampah dan saluran tentang banyaknya populasi lalat pembuangan air limbah yang masih terbuka. Para pedagang sering mengeluh tentang banyaknya populasi lalat dan belum adanya upaya pengendalian lalat yang dilakukan oleh instansi terkait. Keberadaan lalat dapat dijadikan indikator baik buruknya sanitasi di suatu tempat.

Oleh karena itu berdasarkan uraian latar belakang tersebut maka perlu dilakukan penelitian mengenai Perbedaan Kepadatan Lalat Yang Hinggap Pada Fly Grill Yang Berbeda Warna Di Pajak Singa Kota Kabanjahe Kabupaten Karo.

\section{Perumusan Masalah}

Apakah ada perbedaan kepadatan lalat yang hinggap pada Fly Grill yang berbeda warna di Sekitar Pajak Singa Kota Kabanjahe Kabupaten Karo Tahun 2018 ?

\section{METODE PENELITIAN}

\section{Jenis Penelitian}

Penelitian ini merupakan Pra Eksperimen yaitu Postest Only Design dimana dalam rancangan ini perlakuan atau intervensi telah dilakukan $(\mathrm{X})$ kemudian dilakukan pengukuran (observasi) atau posttest (Y). Selama tidak ada kelompok kontrol, hasil Y tidak mungkin dibandingkan dengan yang lain. Rancangan ini sering juga disebut The One Shot Case Study.Rancangan tersebut dapat digambarkan sebagai berikut :

1. untuk pengukuran di siang hari jam 12.00 desain penelitiannya :
1. $X_{1}$
2. $X_{2}----Y_{z}$
3. $\mathrm{X}_{3}$
4. $X_{4}-Y_{4}$ Keterangan:
$\mathrm{X}=$ Warna
5. $\mathrm{X}_{5}$
$\mathrm{Y}=$ Kepadatan lalat pada pengukuran siang

2. Untuk pengukuran di sore hari jam 17.00 desain penelitiannya :
1. $\mathrm{X}_{1}$
2. $X_{2}$
3. $\mathrm{X}_{3}$
4. $\mathrm{X}_{4}$
5. $\mathrm{X}_{5}$

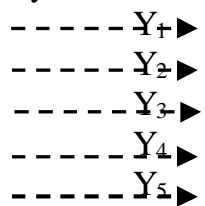

Keterangan : $\mathrm{X}=$ Warna, $\mathrm{Y}=$ Kepadatan lalat pada pengukuran sore

\section{Waktu dan Tempat penelitian}

Penelitian ini dilaksanakan di Sekitar Pajak Singa beralamat di Jalan Kota Cane Kota Kabanjahe Kabupaten Karo. Penelitian ini dilaksanakan dari bulan Juli sampai Oktober 2018

\section{Variabel Penelitian}

1. Variabel Bebas : warna fly grill

2. Varibel Terikat : kepadatan lalat (jumlah lalat yang hinggap pada fly grill)

3. Variabel pengganggu :musim,bau, kelembaban,suhu dan cahaya

\section{Pengumpulan Data}

Alat pengumpulan data yang digunakan adalah a) Fly grill yang berwarna orange, pink, biru muda, hijau muda dan kuning; b) stop watch; c) phsycrometer; d) thermometer; e ) counter; f) alat tulis; dan g) formulir pengukuran kepadatan lalat.

\section{Aspek Pengukuran}

Cara pengukuran yang digunakan dalam penelitian ini adalah dengan menghitung jumlah lalat yang hinggap pada fly grill yang berbeda warna. Pengukuran dilakukan 2 kali 
dalam 1 hari, dilakukan pada siang hari pukul 12.00 dan sore hari pada pukul 17.00 untuk setiap harinya dilakukan pengulangan selama 10 hari dan setiap hari perhitungan dilakukan 10 kali perhitungan kemudian dari 5 kali hasil perhitungan lalat tertinggi dibuat rata-ratanya dan dicatat dalam kartu hasil hitungan (Depkes RI, 1999)

\section{Pengolahan dan Analisa Data}

Uji Statistic menggunakan uji Anova ( Analisis Varians ) dengan $\alpha=0,05$, untuk mengetahui perbedaan kepadatan lalat yang hinggap pada fly grill yang berbeda warna

\section{Hasil Penelitian}

\subsection{Gambaran Umum TPS di Sekitar Pajak Kota Kabanjahe Kabupaten Karo}

Pajak Singa di Kota Kabanjahe adalah salah satu pajak atau pasar di Tanah Karo yang merupakan tempat pertemuan penjual dan pembeli sayur-mayur dan buahbuahan dari beberapa desa di sekiat kecamatan Tigapanah, kecamatan Merek dan kecamatan lain. Kios -kios yang ada di Pajak Singa adalah kios yang menjual buah-buahan, sayur-mayur, rumah makan, daging, bunga-bungaan dan beberapa kios kelontong yang menjual berbagai keperluan rumahtangga seperti roti, gula, garam, sabun dan lain-lain.

Pajak Singa berada di Jalan Kota Cane yang termasuk jalan lintas yang menuju ke Kota Cane dari Kabanjahe dan juga jalan lintas dari beberapa desa ke kota Kabanjahe sehingga jalan tersebut sering sekali macet apalagi pada saat jam kerja antara pukul 07.00 - 14.00 dan sore hari hari jam yang macet sekitar pukul 16.00 -18.00 sore ditambah kondisi pasar yang rusak, tempat pembuangan air limbah yang penuh sampah sehingga keadaan pasar tersebut terlihat sembrawut.

Tempat sampah yang di Pajak Singa ini tersedia 1 buah kontainer sampah dan kriterianya sampah kondisi kedap air, tidak bertutup dan sampah berserakan di sekitar bak sampah dan keadaan di sekitar bak sampah berbau, banyak lalat dan sangat mengganggu estetika dan ada beberapa bak atau container sampah disekitar pajak tersebut. Sampah diangkut oleh petugas kebersihan 1 kali 1 hari sekitar pukul 10.00 WIB pagi dan ada juga beberapa bak atau container sampah diangkut sekitar pukul 13.00 WIB. Petugas dinas kebersihan yang mengangkut sampah juga tidak memakai alat pelindung diri.

\subsection{Jumlah lalat Yang Hinggap}

Tabel 4.1 Rata-rata Pengukuran kepadatan lalat Yang Hinggap Pada Fly Grill di TPS Pajak Singa Kota Kabanjahe Tahun 2018

\begin{tabular}{ccccccc}
\hline $\begin{array}{c}\text { Pengam } \\
\text { atan } \\
\text { Hari Ke }\end{array}$ & \multicolumn{3}{c}{ Kepadatan lalat (ekor/blok grill) } \\
\cline { 2 - 7 } & \multicolumn{3}{c}{ Pink } & \multicolumn{2}{c}{ Orange } & \multicolumn{2}{c}{ Biru muda } \\
& 12.00 & 17.00 & 12.00 & 17.00 & 12.00 & 17.00 \\
$\mathbf{1}$ & WIB & WIB & WIB & WIB & WIB & WIB \\
$\mathbf{2}$ & 10,6 & 7,6 & 5,8 & 4,8 & 3,6 & 5,4 \\
$\mathbf{3}$ & 23,2 & 2,6 & 12,8 & 2,4 & 12,8 & 3,4 \\
$\mathbf{4}$ & 5,6 & 4,6 & 5,2 & 3,6 & 4 & 1,6 \\
$\mathbf{5}$ & 20 & 5,4 & 13,4 & 5 & 14 & 5,8 \\
$\mathbf{6}$ & 11,6 & 3 & 7,6 & 2,6 & 7,8 & 3,6 \\
$\mathbf{7}$ & 8,4 & 2 & 8,2 & 1,2 & 15,6 & 1,6 \\
$\mathbf{8}$ & 2,8 & 3 & 5,4 & 3,4 & 6,2 & 10,4 \\
\hline & 3,8 & 2,8 & 8 & 2,8 & 7,2 & 1,8 \\
\hline
\end{tabular}

\begin{tabular}{|c|c|c|c|c|c|c|}
\hline 9 & 7,2 & 4 & 4,2 & 4,4 & 4,8 & 4,8 \\
\hline 10 & 17 & 14,6 & 9,4 & 10 & 9 & 12,6 \\
\hline Kisaran & $2,8-23,2$ & $2-14,6$ & $4,2-13,4$ & $1,2-10$ & $3,6-15,6$ & $1,6-12,6$ \\
\hline Total & 110,2 & 42 & 80 & 35,4 & 85 & 51 \\
\hline $\boldsymbol{X}$ & 11 & 4,2 & 8 & 3,5 & 8,5 & 5,1 \\
\hline Total & \multicolumn{2}{|c|}{152,2} & \multicolumn{2}{|c|}{115,4} & \multicolumn{2}{|c|}{136} \\
\hline $\begin{array}{l}\text { Rata- } \\
\text { rata }\end{array}$ & \multicolumn{2}{|c|}{7,61} & \multicolumn{2}{|c|}{5,77} & \multicolumn{2}{|c|}{6,8} \\
\hline
\end{tabular}

\begin{tabular}{|c|c|c|c|c|}
\hline \multirow{4}{*}{$\begin{array}{c}\text { Pengam } \\
\text { atan } \\
\text { Hari Ke }\end{array}$} & \multicolumn{4}{|c|}{ Kepadatan lalat (ekor/blok grill) } \\
\hline & \multicolumn{2}{|c|}{ Kuning } & \multicolumn{2}{|c|}{ Hijau Muda } \\
\hline & 12.00 & 17.00 & 12.00 & 17.00 \\
\hline & WIB & WIB & WIB & WIB \\
\hline 1 & 9,4 & 6,8 & 6,8 & 4,6 \\
\hline 2 & 17,6 & 3,2 & 12,2 & 3 \\
\hline 3 & 3,6 & 2,6 & 6 & 2,4 \\
\hline 4 & 8 & 16,6 & 16,6 & 7,2 \\
\hline 5 & 8,2 & 5 & 6,6 & 3 \\
\hline 6 & 19,4 & - & 10 & - \\
\hline 7 & 7,4 & 24,8 & 4,2 & 9 \\
\hline 8 & 11,4 & 3,2 & 3,8 & 2,4 \\
\hline 9 & 10,2 & 5 & 5 & 4,4 \\
\hline 10 & 12,2 & 23,6 & 11,8 & 10,8 \\
\hline Kisaran & $3,6-19,4$ & $0-24,8$ & $3,8-16,6$ & $0-10,8$ \\
\hline Total & 107,4 & 90,8 & 83 & 46,8 \\
\hline$\pi$ & 10,7 & 9,1 & 8,3 & 4,7 \\
\hline Total & \multicolumn{2}{|c|}{198,2} & \multicolumn{2}{|c|}{129,8} \\
\hline $\begin{array}{l}\text { Rata- } \\
\text { rata }\end{array}$ & \multicolumn{2}{|c|}{9,91} & \multicolumn{2}{|c|}{6,49} \\
\hline
\end{tabular}

Berdasarkan tabel 4.1 juga menunjukkan bahwa hasil rata-rata pengukuran kepadatan lalat pada fly grill warna pink yaitu pada pukul 12.00 WIB dan pukul 17.00 WIB sebesar 7,61 (ekor/blok grill), fly grill warna orange sebesar 5,77 (ekor/blok grill), fly grill warna biru muda sebesar 6,8 (ekor/blok grill), fly grill warna kuning sebesar 9,91 (ekor/blok grill) dan warna hijau muda sebesar 6,49 (ekor/blok grill). Dari data hasil uji Anova dengan $\alpha=0,05$ menunjukkan $\mathrm{p}=0,221$ yang berarti bahwa tidak ada perbedaan kepadatan lalat yang hinggap pada fly grill yang berbeda warna. Dengan demikian, dapat dilihat kepadatan lalat tertinggi ada pada fly grill berwarna kuning dibanding fly grill berwarna pink, orange, biru muda dan hijau muda. Pada hasil pengukuran kepadatan lalat yang hinggap pada fly grill di TPS Pajak Singa :

1. Hasil rata -rata pengukuran kepadatan lalat pada fly grill warna pink yaitu pada pukul 12.00 WIB berkisar 2,8-23,2 (ekor/blok grill) dengan hasil rata-rata sebesar 11 dan pukul 17.00 WIB berkisar 2-14,6 (ekor/blok grill) dengan hasil rata-rata sebesar 4,2 (ekor/blok grill).

2. Hasil rata -rata pengukuran kepadatan lalat pada fly grill warna orange yaitu pada pukul 12.00 WIB berkisar 3,6-15,6 (ekor/blok grill) dengan hasil rata-rata sebesar 8 dan pukul 17.00 WIB berkisar 1,2-10 (eker/blek grill) dengan hasil rata-rata sebesar 3,5 (ekor/blok grill).

3. Hasil rata -rata pengukuran kepadatan lalat pada fly grill warna biru muda yaitu pada pukul 12.00 WIB berkisar 3,6-15,6 (ekor/blok grill) dengan hasil rata-rata sebesar 8,5 dan pukul 17.00 WIB berkisar 1,6-12,6 (ekor/blok grill) dengan hasil rata-rata sebesar 5,1 (ekor/blok grill).

4. Hasil rata -rata pengukuran kepadatan lalat pada fly grill warna kuning yaitu pada pukul 12.00 WIB berkisar 3,6-19,4 (ekor/blok grill) dengan hasil rata-rata 
sebesar 10,7 dan pukul 17.00 WIB berkisar 0-24,8 (ekor/blok grill) dengan hasil rata-rata sebesar 9,1 (ekor/blok grill).

5. Hasil rata -rata pengukuran kepadatan lalat pada fly grill warna hijau muda yaitu pada pukul $12.00 \mathrm{WIB}$ berkisar 3,8-16,6 (ekor/blok grill) dengan hasil rata-rata sebesar 8,3 dan pukul 17.00 WIB berkisar 0-10.8 (ekor/blok grill) dengan hasil rata-rata sebesar 4,7 (ekor/blok grill).

Data kepadatan lalat pada berbagai warna fly grill tersebut kemudian dianalisis. Analisis untuk uji Anova maka syaratnya adalah sampel berasal dari kelompok yang independen, variabel factor bersifat non metric (data kategorikal), data masing-masing kelompok berdistribusi normal dan varian antar kelompok harus homogen. Analisis yang pertama adalah Shapiro-Wilk yang untuk memenuhi syarat uji Anova yang distribusi data harus normal.Ternyata setelah data diolah dengan menggunakan SPSS 17 maka data berdistribusi tidak normal karena ada satu data dimana sig $<0,05$, jadi jika data tidak berdistribusi normal, maka perlu dilakukan transformasi data, kemudian uji normalitas ulang menggunakan transformasi data dan ternyata setelah dilakukan Tranformasi Data maka data jadi berdistribusi normal.

Setelah didapatkan bahwa distribusi data adalah normal, maka dilanjutkan dengan uji homogenitas maka diketahui $\mathrm{p}=0,661(\mathrm{p}>\alpha)$ maka telah memenuhi syarat untuk melakukan uji One Way Anova.

\section{PEMBAHASAN}

Jenis lalat yang ada di TPS Pajak Singa sebagian besar adalah lalat rumah (Musca domestica) dan sebagian kecil adalah lalat hijau . Lalat-lalat ini banyak dijumpai di lantai TPS, dimana di lantai itu banyak terdapat jenis sampah yang jatuh dan berserakan karena container tidak ditutp dan container tidak mampu menampung jenis sampah. Lalat-lalat ini hinggap pada sampah basah seperti sampah makanan (sayuran,buah-buahan sisa makanan, dan lainlain), karena lalat membutuhkan air dan protein yang terkandung dalam sampah-sampah itu untuk hidup dan berkembangbiak (Depkes RI, 1992).

Berdasarkan pengukuran kepadatan lalat dengan fly grill warna pink yang paling tinggi pada pukul $12.00 \mathrm{WIB}$ sebesar 11 ekor per block grill dan sore hari pada pukul 17.00 WIB yaitu dengan fly grill warna kuning sebesar 9,1 per ekor per blok grill dimana interpretasinya menyatakan bahwa jika jumlah kepadatan lalat berada pada angka antara 6-20 ekor per blok grill maka dinyatakan bahwa populasi lalat padat dan pengamanan terhadap tempattempat berkembangbiaknya lalat dan tindakan pengendalian ( tinggi/padat ). Tingginya kepadatan lalat ini dapat memebrikan dampak negative yaitun gangguan estetika dan gangguan kesehatan. karena lalat-lalat ini dapat menularkan penyakit Typhoid fever, Paratyphoid fever, Disentri basiler, Disentri amoeba dan lai-lain ( Azwar 1995; Depkes RI, 1992). Apalagi jarak dengan rumah penduduk terdekat $<3$ meter dan dengan Klinik Bersama sejauh 100-200 meter, sedangkan jarak terbang lalat sejauh 200-1.000 meter (Azwar,1995). Hal ini semakin memudahkan penyebaran penyakit yang ditularkan melalui lalat dari pasien Klinik Bersama yang menderita penyakit infeksius ke warga sekitar.

Kepadatan lalat disekitar tempat sampah melebihi 2 ekor per blok grill, perlu dilakukan pemberantasan dan perbaikan pengelolaan sampahnya.

Upaya perbaikan cara pengelolaan sampah yang dapat dilakukan antara lain :

1. Himbauan kepada masyarakat pengguna dan petugas untuk selalu menutup container amroll setiap kali selasai digunakan.

2. Penampungan sampah pada container tidak melebihi daya tampung bak atau container sehingga sampah tidak berserakan.

3. Pembersihan secara rutin lokasi TPS sehingga tidak ada sampah yang berserakan disekitar TPS

4. Pengangkutan sampah ker TPA dilakukan setiap hari dan tidak menyisakan sampah pada TPS.

5. Penggunaan gerobak sampah dengan konstruksi yang memenuhi persyaratan kesehatan antara lain gerobak harus dilengkap dengan tutup atau jarring sampah tidak berserakan sewaktu dalam perjalanan, kontruksi kuat dan dinding bagian dalamnya dilapisi dengan palat logam untuk memudahkan pembersihan.

6. Pembersihan dan pencucian gerobak setiap kali selesai digunakan untuk menghindari kerumunan lalat pada gerobak sampah yang kotor.

7. Pemantauan secara rutin tingkat kepadatan lalat pada TPS dan mealkukan pemberantasan lalat dengan insectisida atau larvasida golongan organophosphate misalnya Diazinon dan Malathion.

Puskesmas terdekat perlu mengadakan penyuluhan kesehatan tentang bahaya lalat kepada masyarakat sekitar karena kesadaran masyarakat tersebut kurang. Mereka kurang peduli terhadap lalat. Apalagi di sekitar TPS warung-warung makanan dan kebanyakan tidak tidak menutup makanan yang mereka jual. Hal ini dapat menyababkan makanan tersebut dihinggapi lalat.

Berdasarkan hasil pengukuran jumlah lalat yang hinggap dan hasil analisis statistic, bahwa lalat mau hinggap dismua warna fly grill. Dalam hal ini semakin banyak lalat yang hinggap berarti warna tersebut lebih disukai lalat.

Berdasarkan rata-rata kepadatan lalat, warna orange, hijau muda dan biru muda mempunyai rata-rata kepadatan yang terkecil. Sehingga disimpulkan bahwa warna biru merupakan salah satu warna yang tidak disukai lalat. Menurut Azwar (1995) lalat takut dengan warna biru. Hal ini kemungkinan disebabkan karena lalat kurang peka terhadap warna biru karena panjang gelombang warna biru pendek dan lalat cenderung bersifat fototropik atau menyukai sinar terang ( Depkes RI, 1992). Sementara itu lalat juga tidak menyukai warna orange dimana warna orange terlihat mirip warna merah dimana kita ketahui bahwa lalat tidak menyukai warna merah karena lalat kurang peka terhadap warna merah karena lalat kekurangan pigmen yang peka (sensitif) terhadap warna 
merah. Hal ini juga terjadi pada sebagian besar serangga yang lain (Nielsen, 1994; Gullan and Cranston,1995).

Berdasarkan hasil penelitian Kusnaedi, lalat lebih tertarik pada warna kuning.Lalat peka terhadap warna kuning, oleh karena itu, warna kuning merupakan kesukaan lalat, dan serangga pada umumnya. Ketika mata lalat menerima rangsangan berupa warna kuning yang ada di alam maka rangsangan tersebut akan diteruskan ke otak melalaui benang syaraf dan oleh otak rangsangan tersebut diolah menjadi warna dengan pola yang mencolok sehingga menarik perhatian lalat. Hal ini juga terjadi ketika serangga-serangga lain mencari nectar pada serbuk sari bunga. Warna kuning serbuk sari tampak mencolok bagi serangga akan menjadi petunjuk sehingga mempermudah serangga dalam pencarian serbuk sari (Nielsen, 1994).

Lalat merupakan serangga yang bersifat fototropik, yaitu menyukai cahaya. Warna dalam ilmu fisika adalah gejala yang timbul karena suatu benda memantulkan cahaya dan mempunyai sifat cahaya bergantung pada panjang gelombang cahaya yang dipantulkan oleh benda tersebut.( Sunarno, 1992).

Serangga memiliki dua tipe mata yaitu mata tunggal dan mata majemuk. Mata majemuk dapat membentuk bayangan mozaik, sedangkan mata tunggal memiliki lensa tunggal yang berfungsi untuk membedakan warna. Kedua mata ini saling bekerja sama terhadap rangsang warnawarna tertentu. Serangga dapat membedakan warna-warna kemungkinan karena adanya perbedaan pada sel-sel retina pada mata serangga. Dibawah lensa-lensa tersebut terdapat dua lapisan sel, yaitu sel korneagen dan sel retina. Sel-sel korneagen yang menyekresi korne bersifat bening pada satu sisi sel retina terdapat bagian yang berdekatan dan bersifat peka cahaya dan terbuat dari mikrovilli yang disebut rebdom. Organ-organ tersebut adalah bagian utama untuk membedakan intensitas cahaya.( A. Hasyim, 2010).

Mata majemuk pada serangga dewasa umumnya terdiri dari dua buah yang letaknya sedemikian rupa dan menonjol, sehingga dapat membedakan lapangan pandangan yang luas. Setiap mata majemuk terdiri dari sejumlah ommatidia yang banyaknya bervariasi tergantung dari jenis serangganya. Mata majemuk lalat rumah terdiri dari 4000 ommatidia. Setiap ommatidia dilengkapi dengan lensa cembung tembus cahaya (cornea), bagian penerima cahaya dan bagian saraf yang berfungsi menangkap radiasi kemudian mengubahnya menjadi energy listrik yang selanjutnya diteruskan ke otak.terangnya bayangan yang diterima oleh setiap ommatidium tergantung pada sudut datangnya cahaya dan gelombang cahaya.

Selain itu, warna mempunyai daya tarik serangga sehingga beberapa serangga menyukai beberapa warna tertentu. Serangga mengenali respon warna yang didasarkan pada kebiasaan serangga tersebut mencari tempat untuk meletakkan telur serangga tersebut. Serangga memiliki system saraf tangga tali yang terdiri dari serangga saraf tubuhnya. Disetiap segmen tubuh,serabut saraf membentuk simpul saraf yang disebut ganglion. Ganglion dalam tubuh serangga ada tiga pasang dan terdapat di kepala dan disebut sebagai protocerebrum. Protocerebrum berada disegmen mata meliputi area yang memiliki pengaruh saraf ocelli dan mata majemuk. Otak adalah pusat panduan dari semua jaringan saraf seluruh tubuh serangga sehingga mengatur perilaku tubuh serangga sesuai dengan rangsangan yang berasal dari luar atau dalam tubuh. Hal ini dapat menyebabkan warna suatu obyek menjadi sumber rangsangan beberapa kelompok serangga untuk melakukan kegiatannya sehari-hari.

Lalat merupakan salah satu serangga yang memiliki mata majemuk yang dapat berkontaksi terhadap warna sehingga prefensinya berbeda pula terhadap warna. Warna kuning merupakan warna yang dianggap paling terang dan paling cerah apabila dibandingkan dengan warna-warna yang lainnya (Supriyadi,1997). Serangga lebih tertarik pada spectrum warna kuning-hijau dengan panjang gelombang 500-600 nm.( Sunarno, 1992).

Dengan mengetahui warna yang paling disukai dan warna paling tidak disukai oleh lalat, maka dapat dilakukan pengendalian lalat, atau setidaknya untuk mengurangi jumlah lalat yang hinggap pada makanan dan minuman serta tempat sampah, yaitu dengan menggunakan alat penutup makanan dan minuman maupun tempat sampah,yaitu dengan menggunakan alat penutup makanan dan minuman maupun tempat sampah yang berwarna orange, hijau muda dan biru muda.

Tempat sampah warna orange, hijau muda dan biru muda sebaiknya digunakan untuk sampah basah, seperti sampah makanan, kotoran hewan dan manusia. Jenis sampah ini sangat disukai lalat karena sampah-sampah ini mudah membusuk dan baunya dapat merangsang atau mengundang lalat serta dalam sampah -sampah tersebut terdapat zat makanan yang dibutuhkan lalat untuk berkembangbiak. Selain itu lalat hanya makan dalam cairan atau makanan basah (Depkes RI, 1992). Dengan pemakaian tempat sampah warna orange, hijau muda dan biru diharapkan dapat mengurangi jumlah lalat yang hinggap, sedangkan tempat sampah warna kuning dan pink dapat digunakan sebagai tempat sampah yang kering.

Lalat memang tertarik pada bau-bauan yang busuk, serta bau dari makanan ataupun minuman yang merangsang (Azwar, 1995). Tetapi dengan menggunakan tempat sampah dan tudung saji makanan dengan warna yang tidak disenangi oleh lalat yaitu warna orange, hijau muda dan biru muda diharapkan setidaknya dapat mengurangi jumlah lalat yang hinggap.

Masyarakat dapat melakukan tindakan pencegahan lalat adalah dengan mencegah jangan sampai betah tinggal dan berbiak dirumah dengan cara :

a. Jagalah selalu kebersihan dan kerapian rumah terutama dapur dan ruang makan yang menjadi tempat favorit bagi lalat.

b. Semua tempat sampah usahakan tertutup

c. Bila perlu, semprot tempat sampah dengan obat pembasmi kuman seperti kaporit, atau dengan insektisida dari golongan organophosphate seperti Diazinon dan Malathion.

d. Sampah basah sebaiknya segera dibuang ke tempat penampungan, jangan dibiarkan lebih dari 12 jam menumpuk dalam rumah.

e. Jagalah makanan dengan cara :

1. Menyimpannya dilemari makan atau kulkas. Ini juga mencegah agar makanan tidak basi, selain 
menghindarkan dari lalat dan binatang lain. Bila ventilasi makan cukup besar, lapisi lagi dengan kawat atau kain kasa agar serangga kecilpun tidak dapat menelusup masuk.

2. Tutup semua makanan yang terhidang di meja atau tempat-tempat terbuka lainnya dengan tudung saji yang lubang-lubangnya relative rapat.

3. Bila perlu, pasanglah pintu dan jendela berkasa yang tidak bisa tembus lalat.

Sedangkan upaya pemberantasan dapat dilakukan dengan cara antara lain pemberantasan secara fisik, misalnya dengan menggunkan alat perangkap, umpan dan alat pembunuh elektrik. Ini cara paling mudah dan aman, namun kurang efektif bila jumlah lalat sangat banyak. Cara ini cocok digunakan pada skala kecil seperti di rumah, rumah sakit, kantor, hotel atau supermarket. Sedangkan pemberantasan lalat secara massal dapat dilakukan secara kimia dengan menggunakan insektisida atau larvasida yang sesuai.

Pemberantasan lalat dapat jua dilakukan secara biologis, seperti memanfaatkan pemangsa atau musuh alami lalat. Di Indonesia, teknik biologis ini hampir tidak pernah dilakukan. Sementara negara-negara lain, seperti Thailand, sering memberantas lalat dengan memanfaatkan sejenis semut kecil berwarna hitam (Phiedoloqelon affinis) untuk mengurangi populasi lalat ditempat-tempat sampah. Cara ini lebih aman dibandingkan penggunaan pestisida (Nurbaya,2005).

Namun cara yang paling efektif dalam menanggulangi lalat adalah dengan cara perilaku hidup sehat, misalnya senantiasa menutup makanan dan minuman serta dengan membuang sampah pada tempat sampah yang tertutup. Disamping itu, perbaikan lingkungan mutlak harus dilakukan karena cara ini juga merupakan cara yang paling efektif cara menanggulangi lalat.

\section{KESIMPULAN DAN SARAN}

\section{Kesimpulan}

1. Rata-rata kepadatan lalat mulai yang terendah sampai tertinggi terdapat pada fly grill sebagai berikut :

a. Fly grill warna orange

b. Fly grill warna hijau muda

c. Fly grill warna biru muda

d. Fly grill warna pink

e. Fly grill warna kuning

1. Warna yang paling disenangi lalat adalah warna kuning

2. Warna yang paling tidak disenangi lalat adalah warna orange

3. Warna lain yang tidak disenangi lalat adalah warna hijau muda dan biru muda.

4. Hasil uji Anova dengan $\alpha=0,05$ menunjukkan $\mathrm{p}=0,221$ yang berarti bahwa tidak ada perbedaan kepadatan lalat yang hinggap pada fly grill yang berbeda warna.

\section{Saran}

1. Masyarakat sebaiknya melakukan upaya pengendalian lalat dengan berbagai cara, antara lain dengan cara fisik, kimia, biologi, perilaku hidup sehat dan perbaikan lingkungan. Namun diantara cara-cara tersebut, perilaku sehat dan perbaikan lingkungan merupakan cara yang paling efektif. Perilaku hidup sehat misalnya menutup makanan dan minuman dengan tudung saji dengan warna yang tidak disukai oleh lalat serta dengan membuang sampah yang bertutup yang berwarna orange, hijau muda atau biru muda.

2. Bagi petugas pengelola TPS agar melakukan perbaikan pengelolaan TPS yaitu selalu menutup container setiap kali selesai dipakai, melakukan pembersihan TPS secara rutin, serta melakukan pemantauan kepadatan lalat secara rutin dan pemberantasan lalat secara rutin.

3. Bagai Dinas kebersihan kota Kabanjahe agar melakukan pengecatan container sampah dengan cat warna yang tidak disukai lalat yaitu orange, hijau muda dan biru muda.

4. Bagi Dinas kesehatan agar melakukan pemantauan rutin terhadap program kerja Puskesmas yaitu program pemantauan dan pemberantasan vector termasuk lalat dan melakukan penyuluhan tentang bahaya lalat kepada masyarakat sekitar

5. Pengukuran kepadatan lalat sebaiknya menggunakan alat pengukur fly grill warna kuning untuk mengetahui tingkat kepadatan lalat.

\section{DAFTAR PUSTAKA}

Ardhiana Rini,2011. Gambaran Sanitasi Dasar Kantin dan Tingkat Kepadatan Lalat pada Kantin Sekolah Menengah Atas (SMA) di Kecamatan Medan Barat Kota Medan.Fakultas Kesehatan Masyarakat.Universitas Sumatera Utara. http//reposytori.usu.ac.id/bitstream/handle/1234567 89/30488/cover.pdf

Azwar A, 1995. Pengantar Ilmu Kesehatan Llingkungan, Jakarta: Mutiara Sumber Widya.

Darmawati et al (2005). Identifikasi dan Hitung Jumlah Bakteri Kontaminan Pada Lalat M.domestica Berdasarkan Lokasi Penangkapan di Rumah Sakit Bhayangkara Semarang. Jurnal Kesehatan Masyarakat Indonesia, Vol.2 (No.2) Avaible from :Google Cendikia (20 September 2016)

DepKes RI, 1991 . Petunjuk Teknis Tentang Pemberantasan Lalat, Jakarta : Ditjen PPM dan PL.Departemen Kesehatan Republik Indonesia 1992 . Petunjuk Teknis Tentang Pemberantasan Lalat, Jakarta : Ditjen PPM dan PL. Departemen Kesehatan Republik Indonesia 2002. Pedoman Teknis Penilaian Rumah Sehat. Jakarta : Ditjen PPM dan PL. 2001.Petunjuk Teknis Pemberantasan Lalat.Jakarta: Direktorat Jenderal PPM dan PL.

Dwiyatmo, K.2007. Pencemaran Lingkungan dan Penangannya. Yogyakarta; Citra Aji Pratama.

El-Sherbini,G.T \& El-Sherbini.,2011. The Role of Cockroaches and Flies In Mechanical Transsmision of Medical Important parasites.Journal of 
Entomology and Nematology,3 (7),pp.98-104. Avaible from :Google Cendikia (9 September 2016).

Gullan.P.J.,Cranston,P.S,1995. Insect : An Outline Of Entomology.Oxford: Alden Press.

Hadiwijoto, S. 1983. Penanganan dan Pemanfaatan Sampah. Penerbit Yayasan Idayu. Jakarta

Hastutiek,P. \& Fitri,L.E., 2007.Potensi Musca domestica Linn. Sebagai Vektor Beberapa Penyakit. Jurnal Kedokteran Brawijaya. 23 (3), pp.125-136. Avaible from :Google Cendikia (9 September 2016).

Hasyim A, 2010. Respon Hama Lalat Buah Jantan Terhadap beberapa Jenis Atraktan dan Warna Perangkap di Kebun Petani.

Hendary,dkk, 2009. Pemanfaatan Sampah.Jakarta PT.Gramedia.

Kusnaedi, 1996. Pengendalian Hama Tanpa Pestisida.Jakarta. Penebar Swadaya.

Neloka, Amos,1020. Kesadaran Lingkungan.Jakarta. Rineka Cipta.

Nielsen, K.S, 1994. Animal Phsiology Adoption And Environmnet Fourin Edition.New York; Cambrigde University Press

Nurbaya H, 2005.Lalatpun Menebar H5N1.Intisari No.43 November 2005.

Onyenwe, E., Okore,O.O., Ubiaru,P.C and Abel,C.2016. Housefly-Borne Heliminth Parasites Of Mouanuand Its Public Helath Imlpication For The University Community. Animal Research International. 13(1),PP.2352-2358. Avaible from :Google Cendikia (2 Oktober 2016)

R.Soemadi, 2008. Sampah. Jakarta. PT.Gramedia

Santi, Devi Nuraini. 2001. Manajemen Pengendalian Lalat. Fakultas Kedokteran. Universitas Sumatera Utara. 5 Halaman (Dipublikasikan)
Sayono,Mardhotillah dan Martini. 2005.Pengaruh Aroma Umpan dan Warna Kertas Perangkap Terhadap Jumlah Lalat Yang Terperangkap. Jurnal Libang.2(2) Available from : Geogle cendikia. (9 September 2016).

Sitanggang T, 2001. Studi Potensi Lalat Sebagai Vektor Mekanik cacaing porasit Melalui Pemeriksaan Eksternal. Skripsi, Fakultas Kedokteran Hewan. Institut Pertanian Bogor.

Sunarno,1992. Ketertarikan Serangga Hama lalat Buah Terhadap Berbagai Papan Perangkap Berwarna Sebagai Salah Satu Teknik Pengendalian. Politeknik Perdamaian Halmahera. Tobelo

Supriyadi,1997. Efisiensi Penangkap Sticky Trap Kuning Pada lalat Pengorok Daun Liriomyza di Pertanaman Bawang Putih.

Suraini, 2013. Jenis-jenis Lalat (Diptera) dan Bakteri Enterobacteriaceae Yang Terdapat di Tempat Pembuangan Akhir Sampah (TPA).53(9),pp.16891699.Available from :Google Cendikia (9 September 2016).

Wardhana, KP., Kurniawan,B. \& Mustofa,S 2014. Identifikasi Telur Soil Transmitted Heminths pada Lalapan Kubis (Brassic oleracea) Di WarungWarung Makan Universitas Lampung. Medical Jurnal Of Lampung University.ISSN 2337-3776, 3(3), pp.87-88. Available from : Geogle cendikia. (9 September 2016).

Widyatmoko, Moerdjoko dan Sintorini, Menghindari, mengolah dan menyingkirkan sampah.Jakarta.Abdi Tandur. 